\section{Tobacco industry shoving its snout under the UN tent flap}

\author{
Ruth E Malone ${ }^{\odot}$
}

The champagne flutes might be lined up at Philip Morris International's (PMI) headquarters in Lausanne near Geneva after a series of recent developments that are extremely troubling for the global tobacco control movement. It may not be widely known to those who associate Switzerland with clean skies, snowy mountains and crystalline lakes, but tobacco multinationals are highly influential there and the country badly lags the rest of the world in implementing strong tobacco control policies to protect its citizens. ${ }^{1}$ Given that Geneva also happens to be the headquarters for the WHO, the country's failure to ratify the WHO Framework Convention on Tobacco Control (FCTC) shows which of the two organisations seem to dominate its government policy. In fact, PMI recently cosponsored the opening of a Swiss government embassy in Moscow and the Swiss Ministry of Foreign Affairs has approved PMI to be the main sponsor of the Swiss Pavilion at Expo 2020 in Dubai. Concerned observers have been noting on social media the increased tobacco industry lobbying of United Nations (UN) officials. ${ }^{2}$

An article appearing in Foreign Policy in early $\mathrm{July}^{3}$ highlighted a shocking memo, sent by Michael Møller on the very last day of his tenure as head of the UN office in Geneva, to UN Secretary-General António Guterres with the appalling suggestion that 'a more nuanced' approach might be warranted in relation to existing policies banning UN agency engagement with tobacco companies. Tobacco companies have long been excluded from such involvement, given the tobacco industry's extensive, well-documented history of deception and the fundamental conflict of interest between public health objectives and the profit-making objectives of tobacco companies. Article 5.3 of the WHO FCTC recognises this conflict and urges Parties to protect tobacco control policies from the vested interests of the tobacco industry. However, 'engagement' with UN and Swiss government

Social and Behavioral Sciences, University of California, San Francisco, CA 94118, USA

Correspondence to Professor Ruth E Malone, Social and Behavioral Sciences, University of California, San Francisco, CA 90095, USA; ruth.malone@ucsf.edu agencies is a cherished goal of PMI and other companies desperate to (re)position themselves as 'part of the solution' to the tobacco problem. Their intent: get the industry snout back under the influential global policy tents where they previously wreaked havoc, and undermine the solidarity of the global tobacco control movement. $^{45}$

The memo noted that the Director-General of WHO had "made it clear he is bound by the decision of the Framework Convention on Tobacco Control to totally exclude the tobacco industry from any contact with the UN system." However, the letter continued, "the policy question remains as to the appropriateness of this total ban, via-a-vis the goal of the Sustainable Development Goals to 'not leave anyone behind". It is touching that Møller was apparently concerned about not leaving tobacco companies behind, but leaving them behind is precisely what global tobacco control efforts are all about. (The myth that smokers in low/middle-income countries are being 'left behind' is being promulgated by tobacco companies through key allies, while ignoring the fact that tobacco companies are aggressively seeking to interfere with effective public health policies and increase smoking in those very same countries.)

Møller noted that the letter was an attempt to raise the issue "at the top political level, following consultations by colleagues with the DSG [Deputy Secretary-General], and with the DG [Director-General] of WHO." One cannot help but wonder precisely who these unnamed "colleagues" may have been and what sorts of connections they have with Big Tobacco. Møller's memo calls to mind the small clutch of former tobacco control leaders who now advocate on behalf of tobacco company positions, despite the ongoing trail of evidence that the fundamental purpose of a tobacco company is to do whatever it takes to sustain profits. Case in point: the PMI-funded Foundation for a Smoke-Free World (FSFW), which continues its efforts to hijack tobacco control leadership. FSFW claims rather patronisingly in its online Strategic Plan that "tobacco companies frequently are shunned, dismissed and barred from engaging by groups that are oblivious to how sectors transform. ${ }^{6 "}$ In fact, what tobacco companies fear most is the profit-reducing sector transformation that global tobacco control efforts are causing, both through evidence-based FCTC policies and through work within the global financial sector.

Those few former leaders, for whom neoliberal economic ideologies and fatter salaries now conveniently align, position themselves as far-sighted visionaries whose grasp of the current 'disruptive moment' is far beyond that of ordinary mortals down in the public health trenches. Willing to disregard the bald fact that selling products ostensibly targeted only for a rapidly shrinking pool of current smokers is not a sustainable business plan, they peddle their smooth new-narrative syrup as though it were not the same old gooey sweetened snake oil that tobacco companies have always attempted to sell to the gormless.

Within less than a week of the letter being published, several major tobacco control organisations operating at the global level, including the Framework Convention Alliance, Action on Smoking and Health, the Campaign for Tobacco-Free Kids, and Stopping Tobacco Organizations and Products, had issued a strong letter in response, noting correctly that "the consensus within the UN system to exclude the tobacco industry from policy making was not created lightly," and characterising the proposal as itself a threat to achieving the Sustainable Development Goals. Such a proposal, their response noted, would be "detrimental to public health but beneficial to the tobacco industry. ${ }^{7 "}$

Only those who simply have not grasped (or have now wiltHEfully chosen to forget) the scale and scope of industry efforts to undermine the full and effective implementation of the FCTC could find the very odd arguments of the Møller document convincing. One especially curious part of the memo noted that 'businesses which are legitimate enough to pay taxes to governments should also be legitimate enough to participate in discussions concerning joint efforts to minimize health risks and address other problems of a common nature." One could as easily argue that the makers of Zyklon-B, the poison gas used in Nazi concentration camps, also paid taxes-but paying taxes did not make the deadly products legitimate nor did it ever make the companies legitimate partners of public health. In fact, taxes are a government measure undertaken to reduce the impact of deadly and dangerous products on the public by reducing consumption-and they work, 
when properly implemented. However, as research published in this journal shows, tobacco companies persist in undermining tax effects by shifting prices of product segments up or down to sustain consumption, and undermining other policies by even more nefarious means. ${ }^{8-11}$

Before his death, the revered tobacco control leader Nigel Gray called the tobacco industry "an anti-social bunch of pathological misfits devoid of any trace of common morality with a facility for poisoning its customers which dwarfs the Borgias, in pursuit of profits beyond even those of the opium trade by selling them a carcinogenic toxic minestrone of unnecessarily addictive chemicals aimed directly at recruiting the underprivileged, uneducated and even the normal into a shortened lifetime of progressive suffocation" (N Gray, personal communication). PMI and its allies now say they really, really do not want to sell that minestrone snake oil any more, but gee, they do not want to give up the profits from doing it, either, so governments ought to help them out. Poor things.

Unfortunately, as of this writing, there has been online silence from WHO and the FCTC Secretariat in direct response to these deeply disturbing developments. They must understand that it is the solidarity of the global tobacco control movement that has got us this far. The FCTC is among the most rapidly and widely embraced treaties in UN history, ratified by over 181 countries, and countering tobacco industry influence is a major factor in its successes. It is only because the tobacco industry fears its eventual demise that it now wants to plead that Big Tobacco has the answers to the problems it continues to create. The tobacco industry and its allies must not prevail in this shameful attempt at renormalisation.

Acknowledgements Thanks to Patricia McDaniel, Pascal Diethelm, Simon Chapman and Joanna Cohen for helpful comments on this editorial.

Funding The authors have not declared a specific grant for this research from any funding agency in the public, commercial or not-for-profit sectors.

Competing interests None declared.

Patient consent for publication Not required.

Provenance and peer review Not commissioned; internally peer reviewed.

(C) Author(s) (or their employer(s)) 2019. No commercial re-use. See rights and permissions. Published by BMJ.

\section{A) Check for updates}

To cite Malone RE. Tob Control 2019;28:479-480.

Tob Control 2019;28:479-480.

doi:10.1136/tobaccocontrol-2019-055309

\section{REFERENCES}

1 Diethelm P. How the tobacco industry undermines public health policy in Switzerland. Sted 2019;28:26-31.
2 Kickbusch I. Twitter post, 2019. Available: https://twittercom/llonaKickbusch/ status/1152479349666406402/photo/1

3 Lynch C. Document of the week: is the U.N. revisiting the ban on big tobacco? foreign Affairs. Available: https://foreignpolicycom/2019/07/12/document-ofthe-week-is-the-u-n-revisiting-the-ban-on-big-tobacco/ [Accessed 12 July 2019].

4 World Health Organisation. Tobacco industry interference with tobacco control. WHO Press, 2008.

5 Ulucanlar S, Fooks GJ, Gilmore AB. The policy dystopia model: an interpretive analysis of tobacco industry political activity. PLoS Med 2016;13:e1002125.

6 Foundation for a Smoke-free World. Context for FSFW 2019-21 strategic plan, 2019. Available: https://wwwsmokefreeworldorg/sites/default/files/ uploads/documents/context_for_fsfw_strategic_ plan_01519pdf

7 Thompson F, Huber L, Myers ML, et al. Joint letter to U.N. Secretary General António Guterres, 2019. Available: https://wwwfctcorg/wp-content/ uploads/2019/07/Joint-letter-to-UN-SG_RE-The-roleof-the-tobacco-industry-in-the-2030-Agenda-final$2 p d f$

8 Gao W, Sanna M, Branston R, et al. Exploiting a low tax system: non-tax-induced cigarette price increases in Taiwan 2011-2016. tobacco control, 2019. Available: https://tobaccocontrol.bmi.com/content/ tobaccocontrol/early/2019/06/04/tobaccocontrol2018-054908.full.pdf

9 Brock B, Choi K, Boyle RG, et al. Tobacco product prices before and after a statewide tobacco tax increase. Tob Control 2016;25:166-73.

10 van Schalkwyk MCl, McKee M, Been JV, et al. Analysis of tobacco industry pricing strategies in 23 European Union countries using commercial pricing data. Tobacco Control, 2019. Available: https:// tobaccocontrol.bmj.com/content/tobaccocontrol/early/ 2019/06/03/tobaccocontrol-2018-054826.full.pdf

11 Bialous SA. Impact of implementation of the WHO FCTC on the tobacco industry's behaviour. Tob Control 2019;28(Suppl 2):s94-6. 